\title{
DANA KEGESITAN (AGILITY FUNDING): SEBUAH MANIFESTO BAGI PEMERINTAH DALAM MENGHADAPI LINGKUNGAN DISRUPTIF
}

\section{AGILITY FUNDING: A MANIFESTO FOR GOVERNMENTS IN FACING A DISRUPTIVE ENVIRONMENT}

\author{
Adi Asmariadi ${ }^{1}$, Dian Sera Fauzzela ${ }^{2}$ \\ Corresponding Author, Badan Penelitian dan Pengembangan Daerah Provinsi Lampung \\ Email: Email: adi_asmariadi@sbm-itb.ac.id, tamajunio@gmail.com
}

Dikirim 22 April 2021, Direvisi 12 Juni 2021, Disetujui 29 Juli 2021

\begin{abstract}
Abstrak: Era disrupsi meningkat, banyak sektor terpengaruh olehnya. Dalam kasus pandemi Covid-19, pemerintah sedang berjuang menghadapi lingkungan yang cepat berubah ini. Sebagaimana diketahui pemerintah memiliki proses penganggaran yang kaku dan birokratis, hal ini menyebabkan pemerintah lamban dalam merespon lingkungan yang cepat berubah. Dengan fokus pada pandemi Covid-19, penelitian ini bertujuan untuk memahami bagaimana pemerintah menanganinya dan kemudian membangun model konseptual untuk solusi. Observasi, studi banding, dan studi benchmarking digunakan untuk pemodelan itu. Alhasil, agility funding menjadi solusi untuk membuat pemerintah gesit menghadapi lingkungan yang disruptif.
\end{abstract}

Kata kunci: Gangguan, Covid19, pemerintah, pendanaan kelincahan.

\begin{abstract}
The age of disruption is rising, many sectors are affected by that. In the case of the Covid-19 pandemic, the government is struggling on facing this fast-changing environment. As known the government has a rigid and bureaucratic budgeting process, this causes the government to slow in responding to the fast-changing environment. By focussing on the Covid-19 pandemic, this research has the purpose of understanding how the government tackles it and then built a conceptual model for a solution. Observation, comparative study, and benchmarking study were used for modeling it. As a result, agility funding is a solution to make the government agile in facing a disruptive environment.
\end{abstract}

Keywords: disruption; Covid-19; government, agility funding

\section{PENDAHULUAN}

Berubah dan terus berubah, begitulah tatanan dunia ini bergerak, dimulai dari teori evolusi yang dicetuskan oleh Charles Darwin hingga munculnya revolusi industri 1.0 sampai 4.0 saat ini. Hakikat dari perubahan selalu diiringi oleh adanya riak bahkan hingga menimbulkan gelombang yang tak terduga. Sebagai contohnya revolusi industri 1.0 yang terjadi pada abad 18 telah memunculkan adanya pemberontakan para buruh akibat pekerjaannya yang banyak tergantikan oleh mesin, peristiwa tersebut dikenal dengan luddite movement (Wren, 2005). Perubahan dapat berlangsung sangat lambat atau bahkan dapat berlangsung seketika. Bila dalam teori evolusi perubahan berlangsung sangat perlahan dan membutuhkan waktu yang lama, maka pada kasus pandemi Covid-19 perubahan tersebut berlangsung secara mendadak. Pandemi Covid-19 menimbulkan gelombang yang memaksa tatanan kehidupan manusia untuk berubah dengan tiba-tiba. Segala lini kehidupan mulai dari tatanan bisnis, pemerintahan, pendidikan, hingga interaksi sosial manusia berubah seketika dengan adanya pandemi Covid-19 tersebut.

Secara garis besar, perubahanperubahan tersebut banyak dipengaruhi oleh lingkungan yang berubah, baik secara perlahan maupun secara cepat. Leher jerapah dalam teori evolusi mengalami perubahan disebabkan karena adanya lingkungan yang berubah, yaitu tingginya daun dalam pohon yang menjadi makanannya. Perubahan dalam revolusi industri 1.0 banyak disebabkan oleh 
penemuan mesin uap yang kemudian merubah lingkungan industri yang sebelumnya menggunakan pekerja manusia tergantikan menjadi mesin. Pada revolusi industri 4.0, proses digitalisasi dalam industri menjadi pemicu adanya perubahan (Almada-Lobo, 2016), yang notabene lingkungan digital lah yang menjadi penyebab adanya perubahan tersebut. Perubahan lingkungan berkaitan erat dengan istilah disruptif yang di dalam Kamus Besar Bahasa Indonesia (KBBI) daring didefinisikan sebagai "Cenderung mengubah atau mengganggu sistem yang sudah ada". Gangguan tersebut tentunya akan merubah tatanan yang ada, karena apabila tatanan tidak ikut berubah, maka kemungkinan besar akan tergerus oleh disrupsi tersebut.

Lalu bagaimana dengan perubahan tatanan kehidupan di masa pandemi Covid19 ini? Banyak negara yang tidak siap dan tergagap-gagap dalam menghadapi perubahan cepat ini. Tak hanya pada tingkatan negara, bahkan pada tingkat internasional dimana Badan Kesehatan Dunia (WHO) pun mengalami kegagapan dalam menangani pandemi tersebut. Hal itu terlihat sebagaimana kasus perubahan anjuran penggunaan masker oleh WHO, yang dilakukan karena anjuran social distancing tidak cukup mampu dalam mencegah penyebaran virus Corona (Shukman, 2020). Covid-19 telah menjadi lingkungan disruptif bagi tatanan kehidupan manusia yang berlangsung secara tiba-tiba. Sektor swasta/bisnis mengalami dampak yang cukup parah, sebagai contohnya pada bisnis bioskop yang harus tutup akibat dampak dari Covid19 (Anwar, 2020). Sistem belajar mengajar di sekolah maupun perguruan tinggi pun ikut berubah seketika, yang sebelumnya dilakukan dengan tatap muka, kini semua beralih secara daring. Tak dipungkiri masih banyak tatanan kehidupan yang lain juga banyak yang ikut berubah akibat pandemi tersebut.

Sektor pemerintahan menjadi sektor yang paling berperan dalam menghadapi pandemi Covid-19 ini, karena berkaitan dengan pengambilan kebijakan untuk menyelamatkan rakyat banyak. Namun sebagai sektor yang paling dominan dalam penggunaan sistem birokrasi, pemerintah menjadi tidak cukup cepat atau gesit dalam menghadapi gelombang perubahan yang diakibatkan oleh pandemi Covid-19 ini. Mekanisme pengganggaran program dan kegiatan pemerintah menggunakan sistem birokrasi yang telah baku dan melalui prosedur yang tidak sederhana. Sistem penganggaran pemerintah menggunakan perencanaan hingga penetapan yang pada akhirnya berbentuk Anggaran Pendapatan dan Belanja Negara/Daerah (APBN/D). Keberadaan APBN/D merupakan instrumen fiskal pemerintah untuk membiayai kegiatan pemerintahan dan pembangunan (Saifuddin, 2020). Keberadaan APBN/D tersebut tidak dapat serta merta diubah begitu saja, karena harus melalui tahapan-tahapan yang perlu dilalui. Tahapan-tahapan tersebut dilakukan dengan tujuan agar anggaran yang notabene berasal dari rakyat tersebut dapat dipertanggungjawabkan dengan baik, atau dapat disebut sebagai dasar dalam menjalankan kepatuhan (compliance) terhadap regulasi. Di sisi lain, kepatuhan tersebut menjadi hambatan bagi pemerintah untuk dapat bergerak cepat menghadapi lingkungan disruptif, sebagai contohnya adalah pandemi Covid-19.

Sistem pengganggaran pemerintahan yang begitu kaku (rigid) menyebabkan program-program pemerintah tidak dapat fleksibel dalam menghadapi perubahan yang cepat (Budi et al., 2018). Pada kasus pandemi Covid-19 sebagai contohnya, pandemi yang mulai masuk di Indonesia pada awal Tahun 2020 apabila dilihat dari mekanisme penganggaran pemerintah, maka pada tahun tersebut tidak terdapat program kegiatan pemerintah yang berkaitan dengan Covid-19. Hal tersebut diakibatkan karena perencanaan APBN/D dilaksanakan pada akhir tahun 2019, dimana Covid-19 belum menyebar di Indonesia. Bila merujuk pada mekanisme 
tersebut, maka pemerintah tidak memiliki anggaran yang diperuntukkan dalam menghadapi pandemi Covid-19. Lalu bagaimana pemerintah di Indonesia dapat tetap melaksanakan program kegiatan untuk menghadapi pandemi Covid-19, padahal secara mekanisme penganggaran hal itu tidak dapat dilakukan?

Penelitian ini bertujuan untuk mempelajari dan mendalami mekanisme pemerintah dalam menghadapi lingkungan disruptif, yang kemudian menjadi bahan dalam pembentukan model penyelenggaraan pemerintah yang dapat dengan cepat menghadapi lingkungan disruptif. Model penganggaran pemerintah untuk bergerak gesit (agile) dalam menghadapi perubahan menjadi preposisi dalam penelitian ini, dengan melihat pada kasus pandemi Covid-19. Pemodelan tersebut diharapkan dapat menjadi masukan ataupun rekomendasi bagi pemerintah dalam membangun sistem pemerintahan yang gesit (agile) dalam menghadapi perubahan yang begitu cepat.

\section{LANDASAN TEORI}

A. Munculnya lingkungan disruptif

Disruption oleh Christensen, dkk. dideskripsikan sebagai "Sebuah proses dimana perusahaan yang lebih kecil dengan sumber daya terbatas mampu dan sukses menantang perusahaan petahana (incumbent) yang sudah berdiri sebelumnya" (Christensen et al., 2015). Pokok dari disruptif adalah kemampuan untuk mencari segmen pasar yang diabaikan oleh perusahaan petahana dan memberikan harga yang lebih rendah. Inovasi disruptif (disruptive innovation) menjadi jalan bagi perusahaan penantang untuk mengganggu bisnis dari perusahaan petahana. Perusahaan penantang akan mulai bekerja pada pasar menengah ke bawah (low end market) untuk meraih segmen pasar yang mulai dilupakan oleh perusahaan petahana. Pasar memiliki struktur seperti piramida, dimana pasar menengah ke bawah memiliki jumlah konsumen yang paling banyak, dan akan semakin menurun jika naik ke atas. Kondisi ini memberikan peluang bagi perusahaan penantang untuk menantang perusahaan petahana dengan memberikan produk yang serupa namun dengan harga yang lebih rendah. Kondisi tersebut tentunya akan memberikan gangguan/disruption bagi perusahaan petahana yang telah memiliki produk tersebut sebelumnya. Contoh dari inovasi disruptif terjadi pada kasus Xerox, sebuah perusahaan pembuat mesin photocopy. Xerox menyasar pasar pada perusahaanperusahaan besar yang membutuhkan mesin photocopy, namun pada akhirnya terdapat perusahaan penantang yang meluncurkan mesin photocopy personal yang menyasar pada individu dan memberikan harga yang lebih murah. Xerox pun terdisrupsi oleh perusahaan penantang tersebut. Gambaran lingkungan disruptif tersebut tak menutup kemungkinan akan menyasar pada sektorsektor lain, bahkan pada sektor pemerintahan.

B. Konsep agility (kegesitan) dalam menghadapi perubahan yang cepat

Konsep agile (gesit) berawal dari ranah pengembangan perangkat lunak, yaitu berawal di tanggal 11-13 Febuari 2001 dimana 17 orang pengembang perangkat lunak berkumpul di The Lodge di Snowbird Ski Resort pegunungan Wasatch, Utah. Perkumpulan tersebut melahirkan Aliansi Pengembangan Perangkat Lunak yang gesit (Agile Software Development Alliance). Dalam perbincangan dan rapat yang mereka lakukan, pada akhirnya terbentuklah Manifesto Pengembangan Perangkat Lunak yang gesit (a Manifesto for Agile Software Development) yang ditandatangani oleh 17 orang tersebut (Martin \& Highsmith, 2001). Manifesto tersebut memiliki 4 nilai dan 12 prinsip, dimana pada dasarnya bertujuan untuk mewujudkan jalan terbaik dalam proses pengembangan perangkat lunak. Nilai-nilai dan prinsip-prinsip dalam manifesto tersebut pada intinya adalah 
membangun konsep pengembangan perangkat lunak yang dapat belajar dan beradaptasi dengan perubahan secara cepat. Sebelum konsep inovasi yang agile berkembang melalui Manifesto for Agile Software Development, ternyata terdapat beberapa konsep yang menyerupai dan menjadi bagian dari sejarah perkembangan konsep agile tersebut. Sebagai permulaan adalah konsep Plan-Do-Study-Act (PDSA) atau Rencanakan-Lakukan-Pelajari-Aksi yang dilakukan oleh Walter Shewhart seorang fisikawan dan juga statistikawan di Bell Labs pada tahun 1930-an (Rigby Darell et al., 2016). Kemudian di tahun 1986 Takeuchi dan Ikujiro Nonaka memperkenalkan pendekatan "rugby" dalam pengembangan sebuah produk. Selanjutnya adalah konsep "scrum" yang diperkenalkan oleh Sutherland dan Ken Schwaber di tahun 1995 yang mampu menyelesaikan suatu proyek secara tepat waktu, dibawah anggaran (hemat), dan dengan kesalahan yang lebih rendah. Hingga di tahun 2001 muncullah konsep agile. Perkembangan agile pun meluas, lima belas tahun kemudian, yaitu di tahun 2016, konsep agile berkembang ke dunia manajemen yang diakui oleh Harvard Business Review, McKinsey \& Company, dan 2015 Learning Consortium Project (Denning, 2016). Bila konsep agile pada awalnya digunakan dalam proses pengembangan perangkat lunak, maka seiring dengan perkembangan zaman, konsep tersebut pun meluas dalam model manajemen. Perkembangan dunia yang bergerak semakin dinamis, tidak pasti, kompleks, dan ambigu mengharuskan sebuah organisasi di era ini untuk dapat bergerak dan beradaptasi dengan cepat dalam menyesuaikan dengan dinamika tersebut. Pola pemasaran yang berdasar pada keinginan pasar (customer-driven) sebagai bahan dalam pengembangan produknya pada akhirnya membutuhkan adanya pengembangan-pengembangan produk baru yang terus menyesuaikan dengan keinginan pasar. Konsep agile akhirnya menjadi jawaban atas pola perkembangan tersebut. Perubahan dan dinamika yang terjadi pada sebuah organisasi dapat segera ditangani apabila organisasi tersebut dapat secara agile menghadapinya. Metode agile pada saat ini telah banyak digunakan oleh perusahaanperusahaan besar dalam mengembangkan produknya, diantaranya seperti National Public Radio yang menggunakan agile sebagai metode untuk membangun program baru, John Deere dalam mengembangkan mesin-mesin baru, dan Saab dalam memproduksi jet tempur. Organisasi yang agile memiliki kemampuan dalam belajar, bertumbuh, dan beradaptasi untuk meraih kesempatan dan juga hal-hal baru yang diinginkan oleh konsumen (Denning, 2016). Transparansi dan perbaikan yang berkelanjutan (continuous improvement) diperlukan dalam proses agile

\section{Bagaimana birokrasi dalam sistem pemerintahan?}

Istilah birokrasi diadopsi secara langsung dari bahasa Inggris, dari kata bureaucracy. Secara etimologis, kata itu berasal dari akar kata "bureau" yang berarti meja tulis, yaitu tempat pejabat biasanya bekerja, ditambah kata "cracy", yang bermakna aturan. Tidak heran bila dalam kamus bahasa Eropa abad ke-18 dan ke-19, istilah birokrasi diartikan sebagai kekuasaan, pengaruh, atau wewenang yang dimiliki oleh para pejabat pemerintahan (Albrow, 1996). Secara ideal birokrasi mengacu pada pemikiran Max Weber, sosiolog Jerman, dari para pendukungnya yang disebut sebagai Birokrasi Weberian (Weberian Bureaucracy). Birokrasi Weberian memiliki ciri utama, yaitu: (1) adanya derajat spesialisasi atau pembagian tugas yang jelas, (2) adanya struktur kewenangan hierarkis dengan batas-batas tanggung jawab yang juga jelas, (3) hubungan antar anggota yang bersifat impersonal, (4) cara pengangkatan atau rekrutmen pegawai yang didasarkan pada kecakapan teknis, dan (5) adanya pemisahan antara urusan dinas dengan 
urusan pribadi yang akan menjamin pelaksanaan tugas secara efisien (Tjokrowinoto, 1995). Kehadiran birokrasi di Indonesia yang peran dan kekuasaannya semakin besar juga dirasakan hampir semua negara berkembang lainnya. Hal ini ditandai dengan kekuasaan politik dan birokrasi yang terpusat pada sekelompok elit dan bersifat sentralistik. Kekuasaan birokrasi yang kuat dan besar di banyak negara berkembang pada satu sisi merupakan warisan kolonial, sementara pada lain sisi merupakan produk dari budaya feodal, terutama sistem hubungan patronage (patron-klien) dan privilege (hak-hak istimewa pada kelompok tertentu) (Wright, 1992). Budi Setiyono (2005) menjelaskan bahwa pada dasarnya birokrasi lahir sebagai produk dari sebuah proses sosial yang panjang dan kompleks yaitu dari serangkaian prosedur yang berliku dan menyangkut kontekstualitas sosial yang universal (Setiyono, 2007), dan dijelaskan sebagai berikut: manusia sebagai individu sekaligus sebagai makhluk sosial jelas tidak mungkin bisa hidup sendiri. Dia membutuhkan orang lain untuk memenuhi kebutuhan-kebutuhannya dan juga agar bisa tetap eksis

\section{$D$. Reformasi birokasi pemerintahan}

Di Indonesia, reformasi birokrasi masih menjadi fokus utama pemerintahan Indonesia. Hal ini didasari keberadaan birokrasi di Indonesia yang belum berjalan sesuai dengan harapan. Hal itu dapat dilihat dari beberapa hasil survei yang menempatkan posisi Indonesia masih tertinggal dibanding dengan negara-negara lain di ASEAN. Global Competitiveness Index 2017 - 2018 yang dirilis oleh World Economic Forum (WEF) pada dokumen Global Competitiveness Report 2017- 2018 menunjukan Indonesia berada diperingkat 36 masih tertinggal dari Thailand (34), Malaysia (23), dan Singapura (3). Dalam Global Competitiveness Report 2017-2018 juga menunjukan belum terakselerasinya peningkatan daya saing indonesia dipengaruhi oleh faktor korupsi, birokrasi pemerintah yang tidak efisien, akses pendanaan, ketidakstabilan kebijakan dan lain-lain. Selain itu, data Global Innovation Index tahun 2017 menunjukan peringkat inovasi Indonesia berada diposisi 87 tertinggal jauh dari Filipina (73), Brunei Darusalam (71), Thailand (51), Vietnam (47), Malaysia (37), dan Singapura (7). Selanjutnya, data mengenai Indeks Efektivitas Pemerintah (IEP) menunjukan bahwa peringkat efektivitas pemerintah Indonesia berada di angka 0,01 pada tahun 2016 masih jauh dari target yang ditetapkan pada Grand Design Reformasi Birokrasi pada tahun 2014 yakni sebesar 0,5. Menanggapi beberapa fakta ini, Presiden Joko Widodo dalam pidato Visi Indonesia yang disampaikan pada tanggal 14 Juli 2019 menyerukan agar instansi pemerintahan melakukan reformasi birokrasi baik secara struktural maupun mindset birokrasi. Tujuannya agar birokrasi di Indonesia menjadi yang semakin sederhana, semakin efektif dan efisien serta menjadi birokrasi yang lincah (Vernanda, 2019). Nilai efektif dan efisien ini sejalan dengan prinsip Good Governance yang diharapkan akan dilakukan pemerintah demi kesejahteraan rakyat (Hidayat, 2018)

\section{E. Agility dalam tata kelola pemerintahan} (agile governance)

Dalam perkembangan pemerintahan yang terjadi, perubahan menjadi salah satu tantangan yang dihadapi. Oleh karena itu, tata kelola pemerintahan yang baik harus mengakomodir perubahan yang ada. Untuk itu tata kelola pemerintahan yang agile (agile governance) menjadi suatu keharusan bagi negara yang mengalami krisis eksistensi di era disrupsi ini. Dalam berbagai kajian, agile governance muncul dalam wilayah organisasi dan mendorong orang untuk menerapkan tata kelola organisasi yang agile (gesit) guna meningkatkan proses kinerja dan produktivitas organisasi (J.H.de O.Luna et al., 2014). Agile governance memiliki 
pengertian sebagai kemampuan organisasi untuk merespon secara cepat perubahan yang tak terduga dalam memenuhi tuntutan dan kebutuhan masyarakat yang semakin berubah (Holmqvist \& Pessi, 2006). Selain itu, agile governance juga diartikan sebagai kemampuan organisasi untuk dapat melakukan efisiensi biaya, serta meningkatkan kecepatan dan ketepatan dalam mengeksploitasi peluang untuk menjadikan tindakan-tindakan inovatif dan kompetitif (Liang et al., 2017).

\section{$F$. Konsepsi hasil penelusuran pustaka}

Penelusuran pustaka-pustaka tersebut memperlihatkan bahwa kecepatan yang terdefinisikan dalam konsep agile menjadi salah satu cara dalam menghadapi perubahan lingkungan yang disruptif. Reformasi birokrasi pemerintahan juga telah menjadi sebuah keniscayaan yang harus segera dilaksanakan. Lingkungan disruptif dapat mengganggu sistem atau tatanan yang telah terbangun, sehingga diperlukan adanya konsep-konsep baru dalam menata sistem yang telah ada.

\section{METODOLOGI}

Penelitian ini menggunakan pendekatan kualitatif melalui pemodelan konsep yang didasarkan dari data-data kualitatif yang tergali dalam penelitian ini. Metode pengkajian pustaka dan observasi kejadian secara cross-sectional dilakukan untuk memahami obyek yang akan diteliti (Saunders \& Lewis, 2012). Pengkajian pustaka dilakukan untuk menggali dan menyusun model konsep yang akan digunakan dalam pemodelan penyelenggaraan pemerintahan yang gesit dalam menghadapi perubahan. Hasil model konsep yang diperoleh kemudian digunakan sebagai preposisi dan landasan dalam penyusunan model penyelenggaraan pemerintahan yang gesit (agile). Kegiatan observasi dilakukan pada proses bagaimana pemerintah dalam menghadapi pandemi Covid-19 yang terjadi pada tahun 2019 hingga 2020. Kebijakan pemerintah
Republik Indonesia dalam menangani pandemi Covid-19 menjadi fokus dalam metode observasi ini. Kajian pembandingan (comparative study) dilakukan untuk mengetahui perbedaanperbedaan yang muncul pada mekanisme penyelenggaraan pemerintah pada kondisi normal dengan mekanisme penyelenggaraan pemerintah pada kondisi disruptif (dengan menggunakan kasus pandemi Covid-19). Setelah proses kajian pembandingan dilakukan, maka kemudian proposisi model konsep disesuaikan dengan hasil temuan dalam kajian pembandingan. Hasil model konsep yang telah terbangun kemudian diuji melalui kajian penyandingan (benchmarking study) terhadap model konsep yang serupa. Proses validasi data menggunakan metode triangulasi terhadap data-data hasil observasi yang telah didapatkan

\section{HASIL DAN PEMBAHASAN}

1. Pembangunan konsepsi pemerintahan yang gesit (agile)

Penelusuran terhadap berbagai pustaka yang berkaitan dengan pola kegesitan (agility), disruption, hingga mekanisme tata kelola pemerintahan menghasilkan sebuah konsepsi penyelenggaraan pemerintahan yang gesit. Konsepsi tersebut diadopsi dari Manifesto Pengembangan Perangkat Lunak yang Gesit yang digunakan oleh para pengembang perangkat lunak yang harus dengan cepat menghadapi perubahan yang terjadi. Konsep pemerintahan yang gesit tersebut memiliki kelayakan karena bersesuaian dengan program reformasi birokrasi yang sedang dijalankan dalam penyelenggaraan pemerintahan. Pemerintah dalam penyelenggaraannya tidak terlepas dari proses penganggaran. Program-program kegiatan pemerintah tidak akan berjalan tanpa adanya sebuah anggaran. Sehingga berkaitan dengan hal tersebut, maka konsep kegesitan yang dibangun dalam penyelenggaraan pemerintah dimulai melalui proses penganggaran yang gesit pula. Susunan 
anggaran pemerintah dikenal dengan nama Anggaran Pendapatan dan Belanja Negara (APBN). Siklus APBN terdiri dari penyusunan \& pembahasan, penetapan, pelaksanaan, laporan realisasi semester I dan prognosis semester II, dan perubahan (Tentang DPR - Dewan Perwakilan Rakyat, 2020). APBN berlangsung selama satu tahun dengan penetapan anggaran dilakukan pada tahun sebelumnya. Bila merujuk pada mekanisme APBN tersebut, maka pada kasus pandemi Covid-19 yang mulai masuk ke Indonesia pada awal tahun 2020 (Pranita, 2020), dipastikan tidak terdapat anggaran dalam APBN yang diperuntukkan bagi penanganan pandemi Covid-19. Hal ini didasari pada mekanisme penetapan anggaran yang dilakukan di tahun sebelumnya, sehingga pada kasus pandemi Covid-19 yang terjadi pada tahun 2021 tidak memiliki anggaran, karena penetapan anggaran dilakukan di tahun 2019. Berdasar pada hasil observasi tersebut, maka konsepsi pemerintahan yang gesit dibangun melalui mekanisme penganggaran yang gesit menghadapi perubahan.

\section{Penyelenggaraan menghadapi pandemi Covid-19.}

Mekanisme penganggaran menjadi masalah utama bagi pemerintah dalam menangani pandemi Covid-19 di Indonesia. Hal yang dilakukan oleh pemerintah Indonesia adalah dengan menerbitkan Peraturan Pemerintah Pengganti UndangUndang Republik Indonesia Nomor 1 Tahun 2020 yang bertujuan untuk menyusun APBN bagi penanganan pandemi Covid-19 dan menghadapi ancaman yang membahayakan perekonomian nasional (Peraturan Pemerintah Pengganti Undang-Undang Republik Indonesia Nomor 1 Tahun 2020 tentang Kebijakan Keuangan Negara dan Stabilitas Sistem Keuangan Untuk Penanganan Pandemi Covid-19 dan/atau Dalam Rangka Menghadapi Ancaman Yang Membahayakan Perekonomian N,
2019). Kebijakan keuangan atau anggaran tersebut merupakan upaya darurat yang dilakukan pemerintah dalam menghadapi perubahan seketika yang diakibatkan oleh pandemi Covid-19. Kebijakan keuangan tersebut dibagi menjadi dua, yaitu kebijakan keuangan negara dan kebijakan keuangan daerah. Dalam kebijakan keuangan negara, pemerintah berwenang melakukan penyesuaian dan pergeseran anggaran serta beberapa tindakan lain yang ditentukan. Kebijakan keuangan daerah diatur mengenai kewenangan pemerintah daerah dalam mengutamakan penggunaan alokasi anggaran untuk kegiatan tertentu (refocusing). Dana kesehatan, dukungan kepada usaha mikro, kecil, dan menengah (UMKM), dan bantuan sosial menjadi sasaran utama dari refocusing anggaran tersebut. Istilah refocusing menjadi kata kunci dari hasil observasi bagaimana kecepatan pemerintah dalam menangani lingkungan yang berubah secara cepat (disruptif)

3. Pemodelan dana kegesitan (agility funding): sebuah manifesto.

Analisis hasil observasi terhadap bagaimana pemerintah menghadapi pandemi Covid-19 menjadi basis dalam menyusun sebuah model pemerintahan yang gesit dalam menghadapi lingkungan disruptif. Konsep pengalokasian anggaran dalam penanggulangan bencana merupakan cara yang dapat diadopsi untuk membangun anggaran pemerintah yang gesit. Sebagaimana diketahui bahwa bencana merupakan peristiwa yang tidak dapat diduga, sehingga dalam penganggaran penanggulangan bencana tidak mungkin dilakukan estimasi perencanaan anggaran sebagaimana umumnya. Pola penganggaran yang dilakukan adalah dengan menetapkan dana siap pakai, yaitu alokasi atau cadangan anggaran penanggulangan bencana yang dapat digunakan saat terjadi tanggap darurat (Undang-Undang Nomor 24 Tahun 2007 tentang Penanggulangan Bencana, 2007). Penggunaan dana siap pakai tersebut 
menggunakan mekanisme khusus dalam proses pertanggungjawabannya. Penyandingan (benchmarking) dari dana siap pakai tersebut kemudian menghasilkan sebuah model dana kegesitan (agility funding) yang dapat digunakan sebagai model konsep penganggaran pemerintah yang lebih fleksibel dan dapat menghadapi perubahan lebih cepat.

Model dana kegesitan dibangun dengan mencadangkan anggaran pada APBN/D yang dapat digunakan seketika saat terjadi perubahan lingkungan yang tak diduga. Perubahan lingkungan tak terduga dimaksud bukan hanya berkaitan dengan kebencanaan, namun dibentuk lebih luas, seperti adanya perubahan teknologi, transisi budaya, sosial, hukum, dll. Sebagai contoh adalah perubahan yang disebabkan oleh teknologi digital, seperti munculnya transportasi daring, belanja daring, dll. Adanya dana kegesitan dapat menangani permasalahan dan dampak yang ditimbulkan akibat adanya perubahan tersebut

\section{KESIMPULAN}

Perubahan tatanan kehidupan yang diakibatkan oleh lingkungan yang mengalami perubahan telah menimbulkan beragam peristiwa sejarah, mulai dari revolusi industri 1.0 sampai 4.0 hingga pandemi Covid-19. Terdapat dua disrupsi yang terjadi di tahun 2019-2020, yaitu dimulainya revolusi industri 4.0 dan di saat yang bersamaan juga terjadi pandemi Covid-19. Disrupsi ganda tersebut tidak hanya berdampak pada sektor swasta, namun juga sektor pemerintah yang bertugas dalam membuat kebijakan. Pola penganggaran pemerintah yang masih menggunakan mekanisme penganggaran satu tahun dirasa tidak cukup cepat dalam menghadapi perubahan cepat. Studi kasus pemerintah dalam menangani pandemi Covid-19 menjadi fokus penelitian ini dalam membangun model konsep pemerintahan yang gesit (agile) menghadapi perubahan. Hasil observasi dan pembandingan dalam penanganan pandemi tersebut, serta penyandingan terhadap mekanisme pendanaan pada penanggulangan bencana, kemudian didapatkan sebuah model konsep berupa dana kegesitan (agility funding). Model konsep dana kegesitan tersebut diharapkan dapat menjadi jawaban bagi pemerintah dalam menangani perubahan, dan menjadi manifesto bagi pemerintah dalam menghadapi lingkungan disruptif.

\section{DAFTAR PUSTAKA}

Albrow, M. (1996). Birokrasi. Tiara Wacana.

Almada-Lobo, F. (2016). The Industry 4.0 revolution and the future of Manufacturing Execution Systems (MES). Journal of Innovation Management, 3(4), 16-21. https://doi.org/10.24840/21830606_003.004_0003.

Anwar, M. C. (2020). Lebih Parah dari Krisis 98, Bisnis Bioskop 2020 Paling Suram. CNBC Indonesia. https://www.cnbcindonesia.com/news /20200715135642-4-172909/lebihparah-dari-krisis-98-bisnis-bioskop2020-paling-suram.

Budi, A. A., Artadita, S., Saifuddin, R., Suharto, Y., \& Dhewanto, W. (2018). Innovation vs Compliance on Indonesia Government. State and Digital Society, International Indonesia Conference on Interdisciplinary Studies, 30-36. http://lppm.unila.ac.id/.

Christensen, C. M., Raynor, M. E., Rory, M., \& McDonald, R. (2015). What is disruptive innovation? Harvard Business Review, 93(12), 44-53. https://doi.org/10.1353/abr.2012.0147.

Denning, S. (2016). What Is Agile? Forbes. https://doi.org/10.2307/j.ctvgd25p.9. 
Hidayat, Taufik. 2018. Kebijakan Pengelolaan Sumber Daya Alam dalam Perspektif Good Governance. Junal Inovasi Pembangunan.Volume 06 No 02, Agustus 2018.

Holmqvist, M., \& Pessi, K. (2006). Agility through scenario development and continuous implementation: A global aftermarket logistics case. European Journal of Information Systems, 15(2), 146-158.

https://doi.org/10.1057/palgrave.ejis.3 000602.

J.H.de O.Luna, A., Kruchten, P., E.Pedrosa, M. L. G. do, Almeida Neto, H. R. d., \& Moura, H. P. d. M. (2014). State of the Art of Agile Governance: A Systematic Review. International Journal of Computer Science and Information Technology, 6(5), 121141.

https://doi.org/10.5121/ijcsit.2014.65 10.

Liang, H., Wang, N., Xue, Y., \& Ge, S. (2017). Unraveling the alignment paradox: How does business-IT alignment shape organizational agility? Information Systems Research, 28(4), 863-879.

https://doi.org/10.1287/isre.2017.071 1 .

Martin, F., \& Highsmith, J. (2001). The Agile Manifesto. Software Development, 9783319101569, 9-14. https://doi.org/10.1007/978-3-31910157-6_3.

Peraturan Pemerintah Pengganti UndangUndang Republik Indonesia Nomor 1 Tahun 2020 tentang Kebijakan Keuangan Negara dan Stabilitas Sistem Keuangan Untuk Penanganan Pandemi Covid-19 dan/atau Dalam Rangka Menghadapi Ancaman Yang Membahayakan Perekonomian $\mathrm{N}$,
2019

46

(2019)..

Pranita, E. (2020). Diumumkan Awal Maret, Ahli: Virus Corona Masuk Indonesia dari Januari. Kompas.Com. https://www.kompas.com/sains/read/2 020/05/11/130600623/diumumkanawal-maret-ahli--virus-corona-masukindonesia-dari-januari.

Rigby Darell, Sutherland Jeff, \& Takeuchi Hirotaka. (2016). The Secret History of Agile Innovation. Harvard Business Review. https://hbr.org/2016/04/thesecret-history-of-agile-innovation.

Saifuddin, Ridwan. 2020. Pemanfaatan Teknologi Informasi dalam Peningkatan Pendapatan Asli Daerah. Jurnal Inovasi Pembangunan. Volume 08 Nomor 02, Agustus 2020.

Saunders, M., \& Lewis, P. (2012). Doing Research in Business \& Management. Pearson Education Limited.

Setiyono, B. (2007). Birokrasi dalam Perspektif Politik \& Administrasi. Puskodak FISIP UNDIP.

Shukman, D. (2020). Coronavirus: WHO advises to wear masks in public areas - BBC News. https://www.bbc.com/news/health52945210.

Tentang DPR - Dewan Perwakilan Rakyat. (2020). DPR.Go.Id. http://www.dpr.go.id/tentang/tugaswewenang

Tjokrowinoto, M. (1995). Pembangunan, Dilema dan Tantangan. Pustaka Pelajar.

Undang-Undang Nomor 24 Tahun 2007 tentang Penanggulangan Bencana, (2007).

Vernanda, R. (2019). Kesiapan Indonesia Menuju Agile Governance. 
Konferensi Nasional Ilmu

Administrasi.

http://180.250.247.102/conference/in

dex.php/knia/article/view/147.

Wren, D. A. (2005). The History of Management Thought (Fifth edit). Wiley.

Wright, C. R. (1992). Sosiologi Komunikasi

Massa. Remaja Karya. 